\title{
HCV Genotype Finding
}

National Cancer Institute

\section{Source}

National Cancer Institute. HCV Genotype Finding. NCI Thesaurus. Code C157506.

The determination of the genotype of hepatitis c virus in a blood sample. 